\title{
STATE POLICY TOWARDS DEMOGRAPHIC CHANGES IN POLAND
}

The process of transformation in Poland, which has been going on since 1989, is described by representatives of various fields of science, publicists and politicians as a complex of system changes of economic, social, political and mental nature. It draws the attention of the whole society, which is both the creator and recipient of reforms, as well as of the world opinion, which determines the place of Poland on the stage of European political relations. It is so because of the sphere of politics, which since 1989 has been trying to enhance the new, democratic political system. It is politics that provides an impulse for economic changes and is a permanent and indispensable element of them. Going further, the relationship between the economy and politics is reflected in social assessments, both decisions and attitudes. The results of politicians' work are evaluated by society, and therefore the acceptance of reforms and the bearing of social costs varies. The positive attitude to change depends on the phase of economic activity and the material situation of society. However, the necessity of transformations, despite their negative consequences, especially the deterioration of the mood in the country and the negative image of the government and the ruling parties, is inevitable. Political negligence carries the risk of economic, social, and ultimately political disadvantage. It is therefore necessary to introduce reforms, taking into account all determinants of state security (with emphasis on demographics), including: geographical and geopolitical, economic and social, educational sphere, health of citizens and cultural factors.

In the face of new phenomena such as monopolies, trade unions, threats to the natural environment, globalisation of the economy and, finally, the threat of demographic regression, the political rationality of the Polish state should focus on a narrow technical and economic sense and a broad social sense. First of all, such areas as education, health care, housing and the labour market should become the rule of conduct and the goal of management. In order to maintain the economic and social balance, which is the basis of state development, it is necessary to supplement the market mechanism where it does not work or works too poorly (Michalewski, 2001: 41-50). First, the welfare of economy, education, health, culture and their rationalization must replace political ambitions, electoral games or incompetence, which is security theory, must be put into practice and make it the purpose of political action. Second, for the effects of transformation to be visible, political change must "go hand in hand" with changes in 
social consciousness. The high expectations of the state in solving emerging problems of the past era should be replaced by social activity, motivation and initiative, which are the most important capital.

Therefore, taking into account the current living conditions of Poles, a good analysis of population phenomena and a realistic demographic forecast for Poland includes a number of disciplines, starting with economics and sociology, through geography, political geography, psychology and ending with medicine. In this context, the respected German statistician and demographer, H. Schubnell emphasizes: "Demographic processes have many aspects: biological, economic, sociological, psychological, socio-medical, anthropological, geographical [...] No science therefore requires interdisciplinary cooperation to the same extent as demography" (Schnubnell, 1971:27).

The priority significance of social policy for demographic problems in Poland is also indicated by E. Rosset (Rosset, 1973: 27-28). In his view, demography and social policy are inseparable:

- one cannot deal with social policy without knowing more about the object of this policy, which is population; thus, a social politician must know demography well; - while studying population relations the demographer cannot confine themselves to the role of a diagnostician: once they have identified this or that deficiency, they must indicate ways of improving it, and this already directs their interests towards social policy.

Demography is thus mutually and reciprocally related, first and foremost, to social policy, but also to other academic disciplines. For example, economic conditions to a large extent determine demographic changes, which in turn affect economic phenomena. Only an interdisciplinary approach to demographic research will make it possible to take advantage of the regularities already detected and to achieve demographic security in theoretical and practical terms.

The analysis of the most important factors of Poland's demographic development, connected, first of all, with the natural movement of the population (including the number of births and deaths as well as internal and external migrations) is an important substantive part and concerns the study of the differences in the state, structure and movement of human populations depending on the factors affecting them (economic, social, geographical, etc). Therefore, the main objective will be to indicate the importance, for the security of Polish society, of such aspects as the economic and social situation of the country, the system of values, the condition of health of the population or the level of health services of the education system and the specific regional distinctiveness of population processes within the Polish territory. Achieving the above goal is important from the point of view of controlling the effects of public administration orders, that is needed to solve the demographic problems faced by the state. A full analysis of aspects of population development will affect the long-term planning of Poland's economic and social development. A further decline in the fertility rate in Poland in the 21st century, below the natural replacement rate, may be a threat leading to a negative natural increase and demographic regression, which has a direct impact on the sustainability of Poland's economic development. Increasing life expectancy additionally intensifies the population ageing process. As a consequence, the burden of the young generations on the older ones increases and " $[\ldots]$ causes the disproportionate 
production capacity of the economy shifts towards servicing and consumption of the elderly. At the same time, the younger people are over-exploited in order to raise sufficiently numerous new generations. An economy oriented towards the consumption of older generations does not invest in research and development. In the long run, it slows down and economic development is reversed." Moreover, A. Sosnowska points to the contemporary fact that young people (of working age) are freed from family or professional ties as a result of industrialization processes.

The authors point to the fact that young people (of working age) are free from family or professional ties as a result of industrialization processes (Sosnowska, 2007: 41-59). What is more, the support of the older generation by the younger one is becoming limited due to, among other things, economic obligations (increase in the number of people receiving pension benefits) and the related division of duties into professional and caring ones. Traditional social security systems will see the impact of state pension systems (the need for contributions to cover retirement benefits) on declining birth rates. First, the chance to raise a large number of children was decreasing. Second, children were no longer "necessary" to provide income in old age. The process of aging in Europe, conventionally since the mid-20th and into the 21 st century, reveals at the same time the need to redefine the role of elderly people on the labor market, to adapt this market to the older demographic structure of the labor force, as well as to discuss changes in the system and retirement age. In conclusion, the demographic survey is intended to provide a foundation for government decisions on population policy. At the same time, it is worth noting that without the impact of extraordinary events, such as a strong Western cultural trend, the realization of demographic security will not be possible. And its primary goal in the conditions of European civilization of the 21st century is to influence the speed and violence of the effects of demographic processes.

The dynamics of the negative demographic processes in Poland which began in the transition period (1989-2001) requires that conclusions be drawn taking into account the historical context and its specific determinants. Taking into account selected demographic indicators such as population growth, mortality, marriage and fertility, one can draw the general conclusion that the period 1989-1992 marked a new downward trend in population processes in the country.

These conclusions raise some basic questions: what kinds of factors influence population changes in Poland? Which aspects determine the demographic security of an area? I. E. Kotowska gives three groups of factors of "new" demographic behaviour in Poland at the end of the 20th and the beginning of the 21st century (Kotowska, 1999: 19):

- structural changes - industrialization, urbanization, development of the service sector, changes in the structure of society and state organization;

- political and world-view transformations - development of democracy and social egalitarianism, increase in the autonomy of individuals, popularity of pluralistic and liberal values;

- technological changes - revolution in contraception and development of medicine, development of telecommunication systems (especially television, telephone, Internet).

On the other hand, B. Balcerzak-Paradowska argues that demographic processes related to family formation and development in Poland are influenced by two types of 
factors (Balcerzak-Paradowska, 2006: 201-219). These include the increased importance of education for young people at the expense of postponing marriage and the birth of the first child. Besides, systemic and structural changes in the labour market, bringing an increase in competitiveness and uncertainty of employment, result in the necessity of strengthening professional position. This means that investments in women's education under new economic, political and social conditions, increase the alternative cost of motherhood. The second type of factors influencing attitudes towards marriage and fertility of the young generation was identified by the authors of the concept of the second demographic transition, R. Lesthaeghe and D. Van de Kaa, and these are: the turn towards post-material values, in favour of the weakening of traditional norms and values (e.g. high fertility, motherhood), order or institutions (including the family), and consequently the increase in the level of education, standard of living or the pursuit of these goals (Bauman, 2006), greater participation of women in social life (in education and on the labour market). The above, in turn, is connected with theoretical interpretations of postmodern society, which indicate the changeability of reality (development, culture, economy), determining the ambivalent attitude towards the role of a parent in the realities of the 21 st century and emphasize the increased importance of such values as: freedom, self-expression, identity, self-fulfillment, freedom of individual choices, weakening of social ties.

To sum up, the contemporary civilization of technological, medical, structural and world-view progress draws attention to the negative changes in the structure of families and the increase in the population of elderly people. In order to be able to talk about further quantitative and qualitative development of the Polish society, the family policy should be oriented towards the removal of barriers. Thus, the contemporary family policy should take into account both the procreative and family context with the participation of the older generation as an important consumer of market services, e.g. recreational, educational, automotive, rehabilitative or cultural services. In the face of negative demographic trends, it is important for the achievement and sustainability of the state of security of future generations to constantly affect the improvement of the quality of life of individuals and families by a number of entities open to social needs in the national as well as regional dimension. In this context, one of the pillars of social policy and law of the European Union and the Council of Europe should be indicated. At this point, it is necessary to point to the solutions adopted in Poland. Council Directive 76/207/EEC of 9 February 1976 on the implementation of the principle of equal treatment for men and women as regards access to employment, vocational training and promotion, and working conditions stipulates that the principle of equal treatment in the field of social security should be implemented first and foremost in statutory systems which provide protection in the event of sickness, disability, old age, accidents at work, occupational diseases and unemployment, as well as in regulations on social assistance to the extent that they are intended to complement or replace the abovementioned systems.

According to the content of the above mentioned Directive (Zwalczanie, 2005), the principle of equal treatment implies the absence of any discrimination whatsoever on grounds of sex, either directly or indirectly by reference to marital or family status, in particular with regards to: the scope of application of the schemes and the conditions 
for coverage by the schemes, the obligation to pay and the calculation of contributions, the calculation of benefits, including increases for a spouse and dependants, and with regards to the conditions governing the duration and retention of entitlement to benefits.

The issue of equalizing the retirement age in Poland is not only a political problem, but also an economic and social one. The current solution is that women reach retirement age five years earlier than men (60 and 65 respectively). In 2010 the Constitutional Tribunal rejected a complaint about the different retirement age for men and women, which does not mean that the different retirement age is in line with the Constitution. The way of calculating the amount of the benefit is discriminatory.

According to a survey conducted by CBOS in 2007 (Wiek emerytalny, 2007), $80 \%$ of respondents believe that the current solution according to which women reach retirement age earlier than men is fair. Over the past five years, opinions on this issue have changed little. In $199587 \%$ of respondents said so, while in 2007 it was $80 \%$. It should be noted that in Poland a seemingly neutral criterion for acquiring pension rights is unfavorable for women. In practice, it means that women who are dismissed from their jobs 5 years earlier than men have limited career opportunities.

Women in Poland can retire without any privileges at the age of 60 , while men at 65 . The new pension system favored an increase in labour force participation, since the amount of pension was made dependent on the period of paid contributions, and the retirement age set in the law represents the minimum age for obtaining rights. According to a survey conducted by CBOS in January $2011,70 \%$ of Poles were against equalizing the retirement age for men and women and raising it to 67 . Women are not interested in extending the retirement age as they perceive it as a loss. Research conducted in 2010 (BAEL 2010) shows that only 16\% of women declare that they resign from their professional career due to family and household responsibilities.

In general, the proposal to lower the retirement age to 60 years for women and 65 years for men had a favorable public reception (Opinie o obniżeniu wieku, 2016). Support for plans to return to the previous retirement age was declared by the total of $84 \%$ of respondents, while it was opposed by the total of $12 \%$. When asked to indicate the single most important - in their opinion - criterion that should determine the acquisition of pension rights, respondents most often indicated length of service (46\%). Age came second (35\%).

Among the acceptable conditions for lowering the retirement age, the largest group of respondents $(48 \%)$ mentioned the requirement to have a sufficiently long insurance period, one in six (16\%) indicated the abolition or significant reduction of the possibility of earning money alongside receiving pension. Raising taxes (5\%) or significantly reducing pension benefits in relation to earnings (4\%) as a condition for lowering the retirement age to 60 for women and 65 for men (Opinie o obniżeniu wieku, 2016) was favoured by the smallest number of supporters.

On October 1, 2017, legislation that restores the retirement age: 60 years for women and 65 years for men came into force. This is a return to the status quo before the 2012 reform, which introduced a gradual increase in the retirement age to 67 regard- 
less of gender (Obwieszczenie, 2017). Research presented by Eurostat in 2020, shows that women receiving pensions in Poland got on average 20.4\% less pension than men. In contrast, the average for all European Union countries was 29\%.

The lowest gaps of less than $10 \%$ were recorded in only two member countries: Estonia $2.4 \%$ and Denmark $7.4 \%$. In contrast, 10 countries had gaps exceeding $30 \%$, with Luxembourg reaching 44.2\%; Spain 31.3\%; Belgium 31.9\%; Italy $33.2 \%$; Germany $36.3 \%$; Austria 36.3\%; Cyprus 38.5\%; Malta 39.5\%; Netherlands 39.7\%.

In a survey conducted in $2017,54 \%$ of respondents planned to stay on the labor market after reaching retirement age. Resignation from professional activity was considered by $28 \%$ of the respondents, according to a survey commissioned by Work Service. At the time, the Social Insurance Institution estimated that about 331,000 people would be able to retire in the last quarter of 2017. The analysis of the survey indicated that the most common motivation for staying on the labor market was the desire to earn extra money (23\%). It should be noted that $13 \%$ of respondents expressed a desire to continue working in order to obtain a higher pension benefit in the future. In contrast, $18 \%$ of respondents planned to stay on the labour market for non-financial reasons. Also of interest are Poles' opinions on how they will retire, especially in the context of the recurring discussion on lowering or raising the retirement age. According to an Aegon study (AEGON 2020), only one in three Poles wants to retire immediately upon reaching retirement age. Another third would like to work fewer hours for a while, while $18 \%$ of respondents said they would be able to change the type and manner of work they do in order to earn extra money while retired. Overall, nearly $60 \%$ of Poles say they intend to retire gradually by working part-time for some time. The employer's measures to enable people to stay longer on the labour market, such as training to improve their skills, age-friendly working environments and promotion of healthy lifestyles, are therefore also important from the point of view of employees.

In Poland, women earn less than men, even though their formal education is higher. It should be noted that women entered the labor market as cheaper labor force (lower education - lower wage level). Stereotypes also play an important role in this case. $\mathrm{J}$. de Bruijn notes that wage provisions in collective bargaining agreements do not apply equally to women and men (Bruijn, 2003: 151). Inequality may be the result of the exclusion of certain jobs performed predominantly by women, from collective agreements or the exclusion of specific employment contracts, especially those concerning women. The main difference between the human capital theory approach and the institutional approach is that in the latter case, wage differences are no longer attributed to individual characteristics of women and men, but to differences in the evaluation of specific jobs - this was also pointed out by the segregationist approach. But while the latter aspires to redistribute women and men across occupations and sectors, the institutional approach mainly aims at changing wages in particular occupations (Bruijn, 2003: 151).

The current unfavorable demographic situation in the European Union raises specific social challenges for demographic policy in the region, especially the problems of demographic growth, strengthening the family, high labor force participation, solidarity between generations, reducing unemployment, poverty and social 
exclusion. It is therefore undeniable that the demographic determinants of the social policies of European countries are closely linked to many areas of life, above all: living and working conditions, ecology, labour market, health care, housing situation, social welfare (Rauziński, Szczygielski, 2010: 125-126). The priority goal of population policy is to influence the processes of family formation and functioning, reproduction, improvement of health and reduction of mortality, as well as migration processes, so that their course is conducive to the formation of an optimal state and structure of the population, ensuring biological continuity and sustainable social and economic development. The implementation of the above-mentioned general objective will be possible if the so-called specific objectives of the demographic policy are met, which include:

a) changes in individual and social attitudes and behaviors toward marriage and family formation;

b) changes in procreation attitudes and behaviours towards implementation of fertility plans (conscious increase of an average fertility level);

c) increasing the quality of life of all generations, especially of the young generation, allowing its "qualitative" development, understood as an improvement in the state of health and the level of education, creating opportunities for full participation in the social, economic and cultural life of the country and in integrated Europe;

d) ensuring active participation of all generations in the demographic and socio-economic development of the country.

In the view of the above, there is a need to define directions of action covering, within the framework of specific policies (in terms of social and economic policy) and the instruments applied by them, the following areas:

- labour (measures for obtaining work and income from it, reducing unemployment, development of entrepreneurship and self-employment);

- social security (family benefits, social insurance, social assistance);

- housing;

- health care (medical services, environment, work environment, nutrition and food, health education);

- education system, including continuing education and family-friendly education (Założenia, 2012: 11-12).

The process of urbanization, professional activation of women, increasing the share of people with higher education are irreversible but desirable structural transformations of the socio-economic sphere of Poland, which result in lower reproduction of the population. Negative demographic trends in Poland require undertaking an active population policy, which would have a wide set of measures at its disposal, depending on the type of social and territorial environment. Therefore, an important issue for the further economic and social development of the country is to define the factors determining the procreative attitudes of potential parents. This task should involve comprehensive and multidisciplinary research. The starting point for population policy is the indication of the criteria for the optimization of states, structures and demographic processes, which entail the need to formulate a general theory of social development, a theory of economic development and the provisions of state policy. 


\title{
REFERENCES
}

Bruijn de J. (2003), Porównywalna wartość pracy i działania na rzecz równej płacy w Unii Europejskiej, in: Ekonomia i płeć, (eds.) A. Geske Dijkstra, J. Plantega, Gdańsk.

Balcerzak-Paradowska B. (2006), Polityka rodzinna wobec starych i nowych wyzwań, in: Sześćdziesiąt lat polityki spotecznej w Polsce, (ed.) A. Rączaszek, Katowice.

Bauman Z. (2006), Plynna nowoczesność, Kraków.

Dyrektywa Rady 76/207/EWG z dnia 9 lutego 1976 roku w sprawie wprowadzenia w życie zasady równego traktowania kobiet i mężczyzn w zakresie dostępu do zatrudnienia, szkoleń i awansu zawodowego, oraz warunków pracy.

Kotowska I. E. (1999), Przemiany demograficzne w Polsce w latach 90. w świetle koncepcji drugiego przejścia demograficznego, "Monografie i Opracowania", No. 461.

Michalewski A. (2001), Wybrane zagadnienia polskiej transformacji, in: Prace z zakresu ekonomii i politologii, (ed.) S. Rudolf, Kielce.

Obwieszczenie Marszałka Sejmu RP z dnia 7 lipca 2017 r. w sprawie ogłoszenia jednolitego tekstu ustawy o emeryturacg i rentach z Funduszu Ubezpieczeń Społecznych, Dz. U. 2017, poz. 1383.

Opinie o obniżeniu wieku emerytalnego (2016), CBOS, Komunikat z badań, Warszawa.

Rauziński R., Szczygielski K. (2010), Demograficzne uwarunkowania polityki społecznej w Unii Europejskiej, in: Międzynarodowa polityka społeczna - aspekty porównawcze, (ed.) A. Balcerzak-Paradowska, Warszawa-Katowice.

Rosset E. (1973), Demografia polska w stużbie postępu społecznego 1946-1971, Warszawa.

Schubnell H. (1971), Bevolkerungswissenchaft und Bevolkerungspolitik, in: Zweite Europaische Bevolkerungskonferenz, Wiesbaden.

Sosnowska A. (2007), Problemy demograficzne starej Europy, in: Procesy demograficzne a kapitat społeczny, (eds.) S. Kluza, K. Plotzke, Z. Sirojć, Warszawa.

Wiek emerytalny kobiet i mężczyzn (2007), CBOS, Komunikat z badań, Warszawa.

Założenia polityki ludnościowej w Polsce (2012), Rządowa Rada Ludnościowa, Warszawa.

Zwalczanie dyskryminacji (2005), Wspólnotowy program działań na rzecz Zwalczania Dyskryminacji 2001-2006, Bruksela.

\begin{abstract}
The aim of the article is to show that the modern civilization of technological, medical, structural and world-view progress determines the negative changes in the structure of families and the growth of the elderly population. Among the research hypotheses, in particular, it should be pointed out that the modern family policy should take into account the procreative context, as well as the family context with the participation of the older generation, as a consumer and participant in market services. The conclusions proposed by the authors concern a number of solutions in the field of social policy. The unfavorable demographic situation in the European Union raises specific challenges for social and demographic policy, among which, we should point out the changes in attitudes and individual behavior towards marriage and starting a family, changes in procreation attitudes, improving the quality of life of all generations, ensuring active participation of all generations in the demographic and socio-economic development
\end{abstract}


of the country. The article has been written using the following research methods: descriptive, comparative and historical analysis.

Keywords: social policy, demographic policy, family, women labour force participation, economic and social development

\section{POLITYKA PAŃSTWA WOBEC PRZEMIAN DEMOGRAFICZNYCH W POLSCE}

\section{STRESZCZENIE}

Celem artykułu jest ukazanie, że współczesna cywilizacja postępu technologicznego, medycznego, strukturalnego i światopoglądowego determinuje negatywne zmiany w strukturze rodzin oraz wzrost populacji osób starszych. Wśród postawionych hipotez badawczych w szczególności wskazać należy na fakt, iż współczesna polityka rodzinna powinna uwzględniać kontekst prokreacyjny, jak i rodzinny z udziałem starszego pokolenia, jako konsumenta i uczestnika usług rynkowych. Wnioski, które proponują autorki dotykają szeregu rozwiązań w zakresie polityki społecznej. Niekorzystna sytuacja demograficzna w Unii Europejskiej wyłania określone wyzwania dla polityki społecznej i demograficznej, wśród których wskazać należy na zmiany w postawach i zachowaniach indywidualnych wobec kwestii zawierania małżeństw i zakładania rodziny, zmiany w postawach prokreacyjnych, podnoszenie jakości życia wszystkich pokoleń, zapewnienie aktywnego uczestnictwa wszystkim pokoleniom w rozwoju demograficznym i społeczno-ekonomicznym kraju. Artykuł powstał z wykorzystaniem następujących metod badawczych: opisowej, porównawczej i analizy historycznej.

Słowa kluczowe: polityka społeczna, polityka demograficzna, rodzina, aktywność zawodowa kobiet, rozwój ekonomiczno-społeczny 
